Article

\title{
The Identity Construction of Migrants on Facebook
}

\author{
Giovanna Mapelli ${ }^{\circ}$
}

Dipartimento di Scienze della Mediazione e di Studi Interculturali, Università degli Studi di Milano, Piazza I. Montanelli, 1_20099 Sesto San Giovanni, Milano, Italy; giovanna.mapelli@unimi.it

Received: 8 May 2019; Accepted: 1 July 2019; Published: 4 July 2019

\begin{abstract}
Social network sites, such as Facebook, allow access to a series of resources or discursive forms that constitute a multimodal and dialogical system that transcends barriers of time and space, favouring transnational communication, something particularly important to migrants. In addition, the comments and dialogues that take place in such socialisation spaces allow us to develop a greater knowledge of the identity and positioning of the user with respect to others. With this work we analyse, from a qualitative point of view, 150 posts each containing at least five comments, published between 2017 and 2019, in each of five Facebook groups of Latin American migrants living in Italy: Uruguayans, Argentinians, Colombians, Peruvians and Venezuelans. We determine their role in the migratory process and how the digital environment affects the relationships between migrants. In addition, we investigate how the identities of migrants are negotiated and (re)defined in discursive practice. Results shows that social network sites are "transnational social spaces", in which a community is based on bonds of solidarity that derive from a shared conception of collective identity, and they forge deterritorialised "community of feeling".
\end{abstract}

Keywords: social networks sites; immigration; identity; transnationalism; Facebook groups

\section{Latin Americans in Italy}

After Spain, Italy is one of the main destination countries of the Latin American diaspora in Europe. The number of migrants from Central and South America has remained constant since 2015: according to the ISTAT data for $2017^{1}$, almost 350,000 Latin Americans (hereafter: LAs) are registered in Italy, representing just under $8 \%$ of the foreign migrant population; to these should be added about 10,000 such migrants without legal status, along with those who have entered the country as descendants of European citizens and those who have obtained Italian citizenship.

For some years now, Peruvians, numbering almost 100,000 and resident Ecuadorians, almost 80,000 , are the most represented nationalities. As for the other nationalities of interest to this study, there are almost 18,000 Colombians, the sixth most numerous group of residents of American backgrounds; Uruguayan migrants are the seventeenth most numerous group with 1200 residents, whilst Argentinians and Venezuelans constitute somewhat lower numbers (occupying the tenth and eleventh positions) with 8000 and 6000 residents respectively. The majority of LAs reside in the northern part of Italy, with the specific epicentre being Lombardy.

It should also be noted that the LA presence in Italy is predominantly female. Indeed, women represent more than $60 \%$ of residents and are, in many cases, the first link in the migration chain, due to their ease in finding work (Caselli 2009). Another relevant aspect of LA migration is the clear tendency towards transnationalism, that is, the simultaneous participation in the family and economic life of their country of origin as well as that of the host country (Boccagni 2009). In addition, these

1 Istituto Nazionale di Statistica (www.istat.it). 
groups tend to be deeply rooted, with very high rates of employment. Their social lives centre around the businesses they establish in the areas of commerce, transport, construction and renovation work, as well as in the sectors of care working and communications (Caselli 2009). In particular, ethnic media and social network sites (SNS) (Chiesi and Zucchetti 2003; Caselli 2009; Mapelli 2010, 2014; Mariottini 2014) give migrants a voice, which allows them to play an active role as protagonists within the information system.

In addition, although the LA presence is not confined to a specific geographical area, there are different urban spaces that represent defined meeting points for ethnic groups and become centres for social contact within the LA communities, such as parks, squares, and churches (Bonomi 2018). In these contexts, Spanish-speaking LA migrants come together to recreate and preserve their customs and traditions and to dialogue in their own language. We also see the formation of very solid SNS that are founded upon a socio-cultural identity deeply rooted in the world of music, dance and gastronomy. These networks, especially when they become highly organised and fully developed, catalyse the process of social integration amongst migrants ${ }^{2}$. Through such groupings migrants are able to develop both socially and intellectually, which facilitates the negotiation of their participation and their effective integration (Garrreta Bochaca 2016). In fact, these associations offer migrants "a sense of belonging and a social significance, helping them, therefore, to position and locate themselves in the new place" (Ferrer et al. 2014, p. 569).

Also, today there are new ways of interrelating people within the digital environment, i.e., SNS, which enable the exchange of experiences and information between peers and represent a fundamental resource for the migrant, since they allow him/her both to create ties between different communities and within the collective itself, and to integrate him or herself within the new social context, avoiding the risks of marginalisation and discomfort.

\section{Theoretical Framework: Identity and Social Network Sites}

This study is based on a theoretical approach that considers identity as a discursive construction and SNS as discursive practices. In this regard, Benwell and Stokoe (2006) state that:

[ ... ] identity has been relocated: from the 'private' realms of cognition and experience, to the 'public' realms of discourse and other semiotic systems of meaning-making. Many commentators therefore argue that rather than being reflected in discourse, identity is actively, ongoingly, dynamically constituted in discourse. (Benwell and Stokoe 2006, p. 4)

Thus, identity is not a static concept, but rather something flexible and dynamic that is constructed within discourse, in our case, in a virtual space. Thus, identity is constantly negotiated, both in interaction and in the narration of personal experiences, in which the speaker signals her positioning in the world and her attitude towards others (De Fina 2006; De Fina et al. 2006). It is something that varies over time, according to a given context and to social relationships (Yus Ramos 2014).

In the new migratory contexts, identities are negotiated and configured (Calvi 2015b). They are often fluctuating, diasporic (Mera 2010) and transnational (Melella 2013), since they go beyond the borders of nation states and promote a constantly hybridised sense of the self. Migrants use identity to negotiate with others and establish closer links within groups.

New technologies mediate social life and migrants have taken advantage of them to shorten distances and build new ways of relating, both with the destination community and with their community of origin. In this way, the internet has fostered a 'connected presence' (Licoppe 2004) in the context of diaspora, in the sense that a new form of 'presence' is possible, which negates distances and the fragmentation that they cause (Diminescu 2008), in favour of an immediate communication.

2 Clearly there is another aspect to such associations: they might complicate the process of migrants' integration into the host community, given the risk of becoming ethnic ghettos leading to ethnic isolation (Leurs and Ponzanesi 2018). 
SNS are fundamental tools with which actors, in this case migrants, constitute and test out their own identities. For example, opening a profile, selecting the profile photo and publishing news, are all actions that contribute to the creation of an interactive identity that amounts to the fusion of social and personal identities. Likewise, the comments and dialogues that emerge in these socialising environments allow to know better the identity and positioning of the user with respect to others (Yus Ramos 2014).

In addition, SNS, such as Facebook, grant access to a series of discursive forms that constitute a multimodal and dialogical system, which facilitates the interconnections between users located in different nations or continents, favouring transnational communication (Vertovec 1999; Boccaglia 2011), something that can be very useful in the case of migrants. In this regard, according to Ambrosini, there are three sectors of transnational activity:

- Economic: represented by the initiatives of transnational entrepreneurs who initiate contacts across borders in search of markets, forms of capital and suppliers;

- Political: in which we place the action of politicians seeking to acquire power;

- Sociocultural: in which we find different categories orientated towards strengthening a sense of national identity abroad or aimed at the collective realisation of cultural events and products that evoke the country of origin (Ambrosini 2008).

\section{Aims and Methodology}

We looked daily at the posts and their corresponding comments published between 2017 and 2019 in five closed Facebook groups ${ }^{3}$ : Uruguayos en Italia (URenIT), Argentina en Italia (ARGenIT), Colombianos en Italia (COLenIT), Venezolanos en Italy (VENenIT) and Peruanos en Italia (PEenIT). We chose different nationalities in order to investigate recurrent linguistic phenomena, rather than the peculiarities related to a given nationality, an aspect that we will explore in future. We built up manually a corpus of 150 posts from each group, and each post contained at least five comments, allowing us to observe the interactive character of the communication. We then carried out a qualitative analysis of the material collected. In this study, we do not systematically consider multimodal aspects of the communications, since they are primarily verbal in nature, to the point where, in most cases, we only see written text. Within a sociolinguistic analytical framework, our objective was to determine the role of these groups in the migratory process. In addition, through the migrant voice, considered as a heuristic tool allowing us to understand the meanings that other people formulate about the world (Hymes 1996), we investigate how identity is negotiated and (re)defined in discursive practice (Knauer 2005) and how relationships between migrants change in the digital environment.

In line with Busso (2016), we define a group as "closed" not so much because it selects the people who access $\mathrm{it}^{4}$, but rather because it is a virtual space that is defined by common interests and a sense of collectivity (Jankowski 2006), as bringing people together, which facilitates the establishment of transnational networks and links that reinforce their own identities as Argentinians, Uruguayans, Colombians, etc.

The use of SNS in the area of migration has been addressed mainly in the field of digital communication and, in particular, digital migration (Diminescu 2008; Komito 2011; McGregor and Siegel 2013; Busso 2016; Leurs and Ponzanesi 2018), or in anthropology (Zijlstra and Liempt 2017),

3 Although there are groups bringing together Latin Americans in general, regardless of their nationalities, such as Somos Latinos en Italia and Latinos en Italia (with 5000 and 3000 members, respectively), there is greater interaction within groups of individual nationalities. Also, there are other groups from these communities, but we chose those that, on 15 June 2017, had more followers: PEenIT have more than 11,000 members; VENenIT more than 8000; ARenIT and COLenIT around 3500 each; URenIT 1500. We excluded the group Ecuadorians in Italy, despite theirs being one of the largest Latin American communities in Italy, because there was no dialogue apparent between the members.

4 In fact, when I applied for membership, they granted me entry within a few days, without asking who I was or why I wanted to join the group. 
psychology (Chen 2010; Ferrer et al. 2014) and sociology (Damian and Ingen 2014). Within the framework of sociolinguistics, studies have focused mainly on semi-directed interviews (with specific regard to Spanish speakers in Italy, see Bonomi 2010, 2018; Calvi 2015a, 2015b among others) and on ethnic media (Mapelli 2010, 2014; Mariottini 2014). However, research on virtual communities is still scarce (Vincent 2015; Kluge 2015). We want to show how migrants forge or (re)construct an identity through discursive practices and to discover whether SNS might be considered transnational social spaces, which tie the country of origin to that of destination, breaking down borders so that two or more nation-states become part of a single social space in which ideas, symbols and cultural material circulate as much as people themselves (Ambrosini 2008). This is an initial approach to how migrants exploit SNS to renegotiate their identities in a new territory, and we leave the analysis of cyberpragmatic aspects (Yus Ramos 2011) for future research.

\section{Analysis of the Facebook Groups}

\subsection{Cover Photo and Information}

Despite not adopting a multimodal perspective, in this article it seems important to consider the cover photo that the administrator chooses to present the group, something the addressee will use to form a hypothesis about the nature of the group in question and the content of the page (Vela Delfa 2014), given that this is the first element with which the user comes into contact.

Uruguay, Venezuela and Argentina opt for their flag and their national colours as a mark of identity; Peru chooses a photo of the World Heritage Site, Machu Picchu; whilst, Colombia displays a famous personality, the cyclist Nairo Quintana, who made history in 2014 as the first Colombian (or, indeed, Latin American) to win the Giro d'Italia.

In the Information section, the target readers and group objectives are defined. In the Peruvian group, for example, it highlights the idea that the group is aimed at Peruvians who "want to share something", whilst the Argentinian page specifies that the group is for "Argentinians who want to meet to share things, help each other, become informed and feel close to home":

1. All Peruvians in Italy who want to share something in common with us all $: \dot{*}$ :) and so remember our lovely PERU !!!!!!!!!!!!!!!!!!!!!!! (PEenIT) $)^{5,6}$

2. For whatever reason, whether long ago or recently, whether alone or accompanied, we all came to Italy from different parts of Argentina. And we meet in a group (as is our custom) to share things, help each other, get informed and feel close to "home", let's make this small space something truly ours. Let's not discuss politics or religion, we know that almost never ends well. Let's not publish things that, rather than helping, annoy others. Let's look after our space together, let's decide what we want to see and what we don't, the group belongs to all its members. Thanks and kisses (ARGenIT)

The Argentinian group has already declared in this section that it is better to avoid discussions about politics or religion, or messages that might offend or annoy other users. It is similarly not uncommon in the other groups to find messages that bring up this topic and invite members to avoid rude language and to respond in a polite manner:

5 Footnotes herein give the original examples verbatim. 6 Todos los peruanos que se encuentran en italia y quieren compartir algo en comun con todos nosotros $\because$ :) asi recordar

7 No importa el motivo, si hace mucho o poco tiempo, si solos o acompañados, llegamos a Italia desde diferentes lugares de Argentina. Y nos reunimos en un grupo (como es costumbre bien nuestra) para compartir cosas, ayudarnos, informarnos y sentirnos cerca de "casa", hagamos entre todos de este pequeño espacio algo bien nuestro. No discutamos de política o de religión, sabemos que casi nunca se llega a buen puerto. No publiquemos cosas que en vez de ayudar, molestan. Cuidemos entre todos nuestro lugar, decidamos que queremos ver y que no, el grupo es de todos sus miembros. Besos y gracias. 
3. Sorry but [ ... ] This group is to "help each other" as Colombians to settle any doubt so to insult or mistreat people who are just looking for information???? Please, if someone asks a question it is because they do not know or want to know more about the subject [ ... ] They don't expect people to come out with rudeness [ ... ] If you know the answer, reply courteously, if not, just move on ... Thank you very much! (COLenIT) ${ }^{8}$

4. Colombians in Italy should be a group of brothers and sisters with mutual respect ... for a convivial moment ... Share beautiful things. Fun things ... that help us escape from some of the sad realities that we live on a daily basis (COLenIT) ${ }^{9}$

The Venezuelan group in Italy has the Italian subtitle "Tutto Venezuela" and, as we shall see later, the use of the language of the host country marks a hybrid identity. This group presents itself as a portal to access Italian services and information; it affirms that here it is possible to find "everything related to Venezuela":

5. Tutto Venezuela where you will find everything related to our country and that only we can offer you in Italy, such as: Gastronomy, National Television Live, the National Press, Events, Photo Galleries, Chat and more (VENenIT) $)^{10}$

The case of Uruguay is peculiar because it indirectly criticises both the Uruguayan and the Italian governments; indeed, it claims that people have had to leave their homeland to come to Italy "because of people like those who govern Italy today":

6. People who left their homeland because of people, like those who govern Italy today, in this group we only accept transparent people, people with no information in their profile are not accepted and I would add that this group is for Uruguayans in Italy and not Uruguayans in the rest of the world (URenIT) ${ }^{11}$

The Colombian group opts for an ironic tone to describe certain situations, customs or characters that they see as typically Italian and that they might meet with—("[people who] have been faced with one or more "tamarros'12"; "have wanted to string up the occasional official at the Questura (Police headquarters)", etc.) or certain beliefs amongst the Colombians ("think that Turin belongs to France"; "have gone to Monza or the San Marino Grand Prix to see Montoya ... "; "are surrounded by the best wines in the world but they just guzzle beer", etc.):

7. For anyone who has ever: faced one or more 'tamarros'. dreamt about stringing up the occasional official at the Questura. [ . . . been] surrounded by the best wines in the world, but just guzzles Irish beer. gone to Monza or the San Marino GP to see Montoya before sunset with a straw hat on. realised that the Tuscan landscape is just like Boyacá. loved the majesty of Rome, the action of Milan, the elegance of Turin, the freshness of Bologna or the beauty of Florence. thought that Turin belongs to France. thought it's at least a little strange that the Italians call themselves Latinos, even though. [ ... ] thought that in Italy male hair removal should be banned (COLenIT) ${ }^{13}$

8 Perdón pero... Este grupo es para "ayudarnos" como colombianos a resolver alguna duda o para insultar o tratar mal a las personas que no saben de alguna información???? Por favor, si alguien hace una pregunta es porque no sabe o quiere profundizar en el tema ... No es para que le salgan con groserias [ ... ] Si usted sabe, responda educadamente, si no, siga derecho... Muchas gracias!

9 Colombianos en italia debe ser un grupo de hermandad de respeto reciproco ..de un momento de relax .... Comparte cosas bellas. Divertentes.... .que logren alejarnos de algunas tristes realidades que vivimos cotidianamente.

10 Tutto Venezuela donde encontraras todo lo relacionado con nuestro país y que solo nosotros te podemos ofrecer en Italia como: Gastronomía, Televisión Nacional en Vivo Prensa Nacionales, Eventos, Galerías de fotos, Chat y algo más.

11 Gente que a dejado su patria. por culpa de gente, como aquella que hoy govierna en italia ,en este gruppo se aceptano solo personas trasparentes, personas que no tienen informacion en el perfil no son aceptadas y agrego este grupo es para los uruguayos en Italia y no los uruguayos en el resto del mundo.

12 'Tamarro' is an Italian colloquial term meaning 'loutish', 'uncouth' or 'ill-mannered', which is used by young people. In this case it has been pluralised by using a Spanish suffix.

13 Para todos los que alguna vez: Le han frenteado a uno o más tamarros. Han querido en sus sueños ahorcar a una funcionaria de la Questura. [ ... ] Tienen a disposición los mejores vinos del mundo, pero se ponen a jartar cerveza irlandesa. Han ido a 


\subsection{Assessment of the Migratory Experience and of the Host Country}

If we read the posts, we realise that the 'wall' is a place where internet users publish their personal concerns and questions about visas, citizenship, residence permits, working, renting, etc. Above all we find requests for practical information and suggestions about living in Italy or about going to Italy; the answers, however, are laid out as accounts of personal migratory experiences, in which migrants use the space autobiographically. These are discursive productions in the first-person singular (Atkinson 1998), in which the subjects construct narratively how they lived certain experiences and how they solved problems related to their arrival in the new country. The use of the first-person singular highlights the active role of the speaker in the narrated events (there are many verbs expressing actions) and their evaluations of situations ("nothing was missing", "it's not easy", "it seems too much"). According to Bauman, there is a tendency to feel able to express more intimate and personal information on Facebook than we would naturally communicate in face-to-face situations; this phenomenon is called "extimacy", which is the constant externalisation of privacy (Bauman 2011). With this approach, persons XXX and ZZZ whose comments aim to demonstrate solidarity with their compatriot, provide relevant answers that demonstrate how he or she has managed to tune in to the host society:

8. $Y Y Y^{14}$ : Hello friends, good morning, sorry for the inconvenience, out of curiosity I started to look into the process of gaining my citizenship and they told me that they are offering chances to apply in about 5 to 7 years' time at the consulate in Córdoba, which seems too long, honestly, but if I go with all the papers to Rome or wherever necessary in Italy, the process is faster, right? Thank you in advance!

XXX: In 2012 at the consulate in Rosario they gave me the number 18654, as of December 31, 2017 they are going to deal with number 14600 , so I still have to wait about 4 or 5 years before they look at my documents.

In Italy, I arrived and applied for residency on February 20 and by June 8 I had my electronic ID in my hand.

ZZZ: I'll tell you my experience, I brought all my documentation complete, there was absolutely nothing missing, it took me 20 days to find a flat to establish my residence, it is not easy to get a contract for just a few months (it has to be totally legal and rubber stamped), then I waited for the time to pass, (between 7 and 45 days), then you present the documentation and wait for them to assess it

In terms of money there were 2 stamp duties of 16 euros, 22.21 euros for the electronic ID card and almost 120 euros for the passport

Of course there is the cost of rent and maintenance because during that time you are not allowed to work.

I carried out the process in Asti, the rent was 350 euros per month plus service charges. (A flat just for me, I did not share with anyone)

The conversion of my driving licence was a bit more expensive because there were several stamp duties and a trip to the consulate in Milan to get the translation done (this is mandatory), in total something like 160 euros in total.

The Tessera Sanitaria [health card] is processed in the hospital, you don't pay anything and it is

Monza o al GP de San Marino ver a Montoya antes de su ocaso con un sombrero vueltiao puesto. Se dan cuenta de que el paisaje toscano es igual al boyacense. Aman la majestuosidad de Roma, la acciòn de Milán, la elegancia de Turín, la fescura de Bologna o la belleza de Florencia. Piensan que Turín pertenece a Francia. Piensan que es al menos un poco extraño que los Italianos se llamen latinos, aunque tengan la razón. [ . . . ] Piensan que en Italia se debería prohibir la depilación masculina.

14 In order to maintain privacy, names of individuals have been omitted. Letters appear when interactions involve multiple participants, in order to distinguish the different comments. 
sent by post to your house.

This is just my experience at the moment (ARGenIT) ${ }^{15}$

It is very common to find messages that show the migrants' determination to face the migratory process. In (10) and (11) there is an attempt to reassure ("you need to relax") the person who is arriving in Italy, by using periphrasis of deontic modality, encouraging them not to give up over administrative procedures ("keep going"). The use of the adversative conjunction "but" mitigates a negative judgment previously expressed ("it's not immediate, but it will happen"; "you can't gain permanent residence straight away but at least you get here") as in (9) and (10):

9. [ ... ] while you are looking for a place to rent you can stay in a room or hostel that you can book from Argentina. From there you can't gain a permanent residence straight away but at least you can get here with an assured bed, nobody can stop you from being a tourist during the time you need until you can rent something (ARGenIT) ${ }^{16}$

10. I arrived on February 2 and started looking, on the 15th I signed a contract with the estate agent, they need to get it stamped and on the 20th I was able to go to the public registry and establish my residence. It is not immediate, but it will happen. If you get that far you need to relax and stick with it (ARGenIT) ${ }^{17}$

11. Keep going in your work a Colombian brother wishes you the best of luck (COLenIT) ${ }^{18}$

Examples (12)-(15) underline the wish not to disturb the dreams of those who want to start a new life. The social network in this case plays the role of attracting people. Those who are already in Italy feel an obligation to be honest with their compatriots, explaining that living in another country is not easy, but try not to discourage them. The important thing is each person's faith and determination to emigrate and, above all, his or her ability to adapt to the new context:

12. No matter what happens, the faith to go on, that everything can be resolved, even if reality shows us something to the contrary. People can tell you a thousand things but only you can live your own experiences, whatever we might tell you, or suggest, is irrelevant if you hang on to the conviction that you will achieve what you want to. Good luck (PEenIT) ${ }^{19}$

13. If you are strong you will achieve everything, I wish you the best of luck from the bottom of my heart $(\text { COLenIT })^{20}$

15 YYY: Hola amigos, buen día, disculpen la molestia, por curiosidad me puse a averiguar para tramitar mi ciudadanía y me dijeron que están dando turnos para dentro de 5 a 7 años en el consulado de Córdoba y me parece demasiado, honestamente, pero si yo voy con todos los papeles a Roma o dónde sea necesario allá en Italia es más rápido el proceso, no? Muchas gracias desde ya! XXX: En el año 2012 en el consulado de Rosario me dieron el número 18654, al 31 de diciembre de 2017 van a atender el 14600, o sea todavía me faltan aproximadamente 4 ó 5 años para que me reciban la carpeta. En Italia, llegue e hice residencia el 20 de febrero y el 8 de junio ya tenía mi DNI electrónico en la mano. ZZZ: Yo cuento mi experiencia, traje mi documentación completa, no faltaba absolutamente nada, demore 20 días en conseguir piso para fijar residencia, no es fácil hacer un contrato por pocos meses (debe ser totalmente legal y estar sellado), luego espere que pase el vigile, (entre 7 y 45 días), después presentar la documentación y esperar que ellos evalúen. Con respecto al dinero fueron 2 sellados de 16 euros, 22.21 euros la carta de identidad electrónica y casi 120 euros el pasaporte. Por supuesto esta el gasto del alquiler y la manutención porque en ese lapso de tiempo no podes trabajar. Yo hice el trámite en Asti, el alquiler fueron 350 euros por mes mas gastos de servicios. (Un piso para mi sola, no compartía con nadie). La conversión del registro de conducir me salio un poco mas cara porque fueron varios sellados y un viaje a Milano al consulado para que hagan ellos la traducción (es obligatorio), en total algo así como 160 euros en total. La tessera sanitaria se gestiona en el hospital, no se abona nada y te llega por correo a tu domicilio. Esto es estrictamente mi experiencia en este momento.

$16[\ldots]$ mientras buscás un lugar para alquilar podes parar en una habitación o albergue que podes reservar desde Argentina. Por ahí no podrás fijar residencia inmediatamente pero al menos llegas con una cama segura, nadie te puede impedir que estés como turista el tiempo que necesites hasta poder alquilar algo.

17 Yo llegue el 2 de febrero y empecé a buscar, el 15 hice el contrato en la inmobiliaria, deben sellarlo y el 20 pude ir al comune y fijar residencia. No es inmediato, pero se consigue. Si venís a eso tenés que relajarte y ser constante.

18 Sigue adelante en tu trabajo un hermano colombiano te desea mucha suerte.

19 Pase lo que pase la fe por delante que todo se puede solucinar aunque la realidad nos muestre todo lo contrario. Cada uno te puede decir mil cosas pero tus experiencias solo las puedes vivir tu, lo que podamos decirte, sugerirte es irrelevante si tienes la convicción de que lo que te propones lo vas a lograr. Suerte.

20 Si eres fuerte logras todo, buena suerte te deseo de corazón. 
14. Having no-one else is a difficult situation but if your dream is here, come (URenIT) ${ }^{21}$

15. In terms of work it's not easy either but if you adapt to doing anything (care worker, babysitter, kitchen assistant, bar worker, I mean humble things) you might get work! (URenIT) ${ }^{22}$

The trip to Italy or the obtention of citizenship require a long wait. Example (16) betrays a certain emotional intensity, by relating the mood of a young woman on the day she leaves Argentina. There are emotive vocabulary ("dreams" and "emotions"), or words that evoke strength and resistance ("never lower our sights"):

16. Fulfil your dreams if you are strong enough [ ... ] friends, the day has arrived, Italy awaits me, I take a suitcase full of dreams and mixed emotions, I hope we can all achieve our dreams never lower our sights! (ARGenIT) ${ }^{23}$

Nevertheless, some emphasise their identity of origin and their love for their homeland, noting that the feeling for the motherland does not change:

17. A document does not change your feeling for your country, but it does make life easier (I'm thinking of the bureaucratic aspect) (PEenIT) ${ }^{24}$

LA migration is characterised by good integration into the receiving community (Calvi 2011; Bonomi 2018); in fact, a positive vision emerges of Italy and the Italians. Again, negative evaluations are always mitigated, in (18)-(20), through the oppositional conjunction "but":

18. The situation will be difficult but better here than in Venezuela (VENenIT) $)^{25}$

19. It's not easy but it's not impossible either [ . . ] ] (URenIT) ${ }^{26}$

20. These days, Italy is not the best country for migrants but probably anything is better today than Venezuela (VENenIT) ${ }^{27}$

Moreover, it should be pointed out that LA migrants do not look down on the Italian people, their discontent stems from the crisis that the country is going through, something that also affects the Italians themselves:

21. People gave me a warm welcome (ARGenIT) ${ }^{28}$

22. It's not the Italians' fault but the crisis that's affecting Italy (URenIT) ${ }^{29}$

23. It's not the best time. Italy is not good at the moment the Italians have no work so imagine the immigrants (COLenIT) $)^{30}$

Italy's natural and cultural beauty is also appreciated: on the Facebook wall, users publish pictures of the Italian landscape, with which immigrants of various nationalities "fall in love". This is another sign of their transnational identity, which is divided between their love for their country of origin and that for their destination country:

24. The sunset today, less than an hour ago, at the Spiaggia Le Ghiaie, in Portoferraio. I fell in love with the Isle of Elba $\bigcirc \bigcirc\left(\right.$ ARGenIT) ${ }^{31}$

21 Sin tener a nadie es una situación difícil pero si es tu sueño aquí véngase.

22 A nivel de trabajo tampoco es facil pero si te adaptas a hacer cualquier cosa (badante, babysitter, ayudante de cocina, mesonero, bueno cosas humildes) puede ser que consigas trabajo!

23 Cumple sus sueños quien resiste ... amigos llegó el día Italia me espera, me llevo una valija llena de sueños y mezclas de emociones, espero que todos podamos lograr nuestros sueños a no bajar los brazos!

24 Un documento no te cambia un sentimiento por tu patria, pero te hace la vida más fácil (hablo siempre de un aspecto burocratico).

25 La situación será fea pero mejor aquí que en Venezuela.

26 No es fácil pero tampoco es imposible.

27 Italia no es hoy el mejor pais para el inmigrante pero seguramente cualquier cosa es mejor hoy que Venezuela.

28 La gente me acogió muy bien.

29 No es culpa de los italianos sino de la crisis que afecta a Italia.

30 No es el mejor momento. Italia esta mal en este momento no tienen trabajo los italianos imagínese inmigrantes.

31 El atardecer de hoy, hace menos de una hora, en la Spiaggia Le Ghiaie, en Portoferraio. Me enamoré de la Isla de Elba. 


\subsection{Assessment of the Active Participation in the Destination Country}

Another aspect that should be highlighted here is that the 'wall' serves as a bulletin board to advertise restaurants, shops selling typical products, and travel agencies run by LAs, which emphasises the business success achieved in the host country and, therefore, the LA migrants' transnational identities.

Likewise, members of the LA community who have reached important positions and that give rise to national pride are celebrated. At the same time, there is also praise for the Italians ("lovely recognition on the part of the citizens") who have given such LAs the opportunity to reach these positions (Council candidate in the local elections, tram driver):

25. Today [... ] our compatriot Liliana Bermudez is participating in the local elections as a candidate for the council. This is a lovely example of recognition from the citizens of this welcoming and picturesque little town of Verona. COLOMBIAN Pride (COLenIT) ${ }^{32}$

\section{Peruvian Pride in Florence ITALY: FIRST PERUVIAN TRAM DRIVER IN ITALY (PEenIT) ${ }^{33}$}

Highlighting the active participation of LA migrants in the social life within the local context, we see publicity for initiatives linked to the culture of the country of origin ("In Imperia we are celebrating the Feast of the National Flag", "Inti Raymi, Festa del Sole"). Sometimes, the group members themselves are seeking information about cultural or sporting events in order to "reconnect with their roots". Once again, we observe a need to maintain an identity of origin, despite the geographical distances:

27. Hello, where can I find a celebration for the 28th (for the Independence Day) recommendations please, I need to reconnect with my roots. Thanks (PEenIT) ${ }^{34}$

28. Is there a bar in Milan to see the Boca match? (ARGenIT) $)^{35}$

\subsection{The Value of Our Roots}

The importance of the country of origin is especially evident in the comments about daily news, which often include complaints and a deep discontent over the serious economic, political and social situation; social media allow a virtual participation in the political life of the country of origin. In (29)-(30) we see the use of vocabulary with negative connotations for the country of origin ("corruption", "poverty", "theft", "laziness"), with the aim of encouraging people to improve the situation, as seen in (31):

29. Corruption and laziness don't allow these regions to progress they are given a great deal of aid. But the leaders steal it all (VENenIT) ${ }^{36}$

30. This referendum will barely solve anything of the problems in Peru, and it certainly won't end the corruption!! (PEenIT) $)^{37}$

In this regard, we note that at times of elections or referendums, several messages are published with information on how to vote from abroad.

Despite living in another country, migrants feel a need to exercise their rights and remain emotionally involved. Expressions such as "pure blood" and "all strength to Peru" give away the Peruvians' sense of pride:

32 Hoy [... ] nuestra compatriota Liliana Bermudez participa a las elecciones comunales como candidato al consejo. Este es un lindo ejemplo de reconocimiento de parte de los ciudadanos de este acogedor y pintoresco pueblito verones. Orgullo COLOMBIANO.

33 Orgullo Peruano en Florencia ITALIA: PRIMERA CONDUCTORA PERUANA DE TRANVIA EN ITALIA.

34 Hola, donde habra fiesta por 28 (x el dia de la independencia)? recomendaciones por favor, Necesito reencontrarme con mis raices. Gracias.

35 Hay algún bar en Milán dónde ver el Partido del Boca?

36 La corrupción y la pereza no dejan progresar esas regiones ayudas se dan y muchas. Pero los lideres se la roban.

37 Con dicho referendum no se solucionara casi nada de los problemas que tiene Perú ni mucho menos se acabara la corrupción!! 
31. It is time to exercise our rights as true- and ancestrally-blooded Peruvians, so now, more than ever, all strength to Peru (PEenIT) ${ }^{38}$

There are also some examples of economic transnationalism (Portes et al. 1999), since some LA businessmen or entrepreneurs seek partners in Italy; this shows that some business activities transcend borders and no longer require a physical infrastructure, but take advantage of digital networks in order to sell products or for consultations, for example. We also note the proliferation of shops selling food and ethnic products, which are advertised in these groups. Similarly, we find publicity for the sale or rental of flats in certain Latinamerican cities:

32. Business opportunity. I am looking for a partner in Rome. Someone who likes Sales, either in person or through social media [ ... ] send me a WhatsApp (Colombian telephone number) $(\text { COLenIT })^{39}$

33. You are invited to get to know my holiday apartment in $\mathbf{X X}, \mathbf{X X}$ available for families and groups of up to eight people $[\ldots](\text { COLenIT })^{40}$

Food has an important role in the construction of identity (De Fina 2007). The LAs who write in these groups also want to know where they can find certain typical products from their homelands or express their happiness at seeing restaurants serving traditional food, since this is a way in which they can recreate in Italy the social practices of their countries of origin and feel as if they were back home:

34. Where can I find PAN ${ }^{\circledR}$ flour? (COLenIT) ${ }^{41}$

35. How lovely to know that I can taste the delights of my homeland (PEenIT) ${ }^{42}$

Migratory transnationalism is above all related to the sphere of the family (Boccagni 2009); an important issue emerging from the posts is that of the social ties with family members who have remained in the country of origin, as shown by remittances and the exchanges of goods (36)-(37) as well as the sporadic visits or the decision to return permanently (38):

36. Hello friends, I am currently in Rosario, and I am returning to Italy on July 25, if someone needs me to bring over anything, any documents I can do that ... let me know and we'll fix it up $(\mathrm{ARGenIT})^{43}$

37. Has anyone sent money to Colombia with small World? (COLenIT) $)^{44}$

38. XXX: I'm going to return to Colombia and I want to send at least one suitcase by courier YYY: I'm also going back!!! Decision made (COLenIT) ${ }^{45}$

\subsection{Social Identification}

In terms of relationships with compatriots, we observe that there is a maintenance of a marked ethnic identity, which is manifested in a constant search for fellow countrymen and women living nearby. The use of adjectives that indicate nationality is very frequent: "Any Argentinians in Messina?"; "Any Colombians in Monza?"; "Any Venezuelan friends in Milan?" It is interesting to note that within these groups, the sense of national identity is very strong and they are never subsumed under the

38 Es tiempo de reclamar nuestros derechos como peruanos de sangre pura y milenaria por eso más que nunca fuerza Perú.

39 Oportunidad de negocio. Busco socio en Roma. Que le gusten las ventas, en persona y por redes sociales [ ... ] envíame un whatsapp (telefono colombiano).

40 Los invito a conocer mi apartamento de vacaciones en $\mathrm{XX}, \mathrm{XX}$ disponible para familia y grupos de hasta ocho personas [ ... ].

41 ¿Dónde puedo encontrar harina PAN?

42 Que bello saber que podré ir a saborear las delicias de mi tierra.

43 Hola amigos, yo ahora estoy en Rosario, y vuelvo a italia el 25 de julio, si a alguien le sirve algo que le lleve alguna cosa, algun documento yo lo puedo hacer... me avisan y arreglamos.

44 Alguien ha enviado dinero a Colombia con small World?

45 XXX: Me voy a regresar a Colombia y quiero enviar al menos una maleta por courrier; YYY: Yo también me devolvi!!! Decision acertada. 
supranational label "Latino" (Calvi 2015a; De Fina 2014; Kluge 2015), which is used exclusively in posters advertising some of the activities publicised in the various groups: Rutas Latinas Envio (cargo distribution network from Italy to Latin America), Aventura Latina (travel agency), used in order to reach a wider audience ${ }^{46}$.

Sometimes, the reference to compatriots is indirect, for instance, when someone mentions a cultural element (e.g., "mate" - a popular infusion shared in Argentina): "Good People! How goes it? Anyone in Savona around to drink some mates?" It is interesting to note that "mate" is a very recurrent cultural symbol in the posts of Argentinians, as we will also see in Example (39) and reveals the importance of the past and the country of origin. Moreover, it should be noted that it also appeared for a while in the group's cover photo, as a symbol of the country.

The formulas that migrants use to address other members of the group are an index of their desire to approach other people in the same situation: they are unifying appellations that emphasise closeness and intimacy, despite the fact that users do not know each other personally.

Thus, some posts include the words friend" or brother, or allude to their shared place of origin, such as a countryman or compatriot. In addition, the use of the participatory we marks group membership and denotes strong emotional involvement and attachment to the country of origin, above all when users talk about Peru or Colombia. There are many expressions like "all of us", "our beautiful Peru", "our beloved Peru", "my lovely homeland", "I love you Peru", "long live our Homeland", and "our beautiful homeland".

In (39)-(40) there is a very strong sense of belonging to the national group. Argentinians, for example, miss the peculiarities of friendship and character that, according to them, Italians do not possess ("Argentinians are unique", "it will never be the same as Argentinian friendship"):

39. ZZZ: Hello everyone, a year ago I came to live in Italy, [ . . ] I don't know about you, but I personally still find it difficult to understand how the Italians relate as friends. Argentinians are unique and I miss my friends [ ... ] If anyone is in this area and wants to have a chat or share a bit, we can fix something up one day. Kisses to everyone!

XXX: It would be good to put on a great barbecue with a really long table and all get together!!!! YYY: You're invited whenever you like bring the mate I don't have any haha 3 (ARGenIT) ${ }^{47}$

40. I was lucky enough to meet some very nice guys from Torino who introduced me to more people, but it will never be the same as Argentinian friendship (ARGenIT) ${ }^{48}$

In (41) the collaborative spirit that characterises these communities stands out, an endogroup attitude emerges, for instance in (41), when the speaker expresses that she or he wants a Colombian babysitter (female):

41. Hi, I'm still looking for a nanny, part time I'm offering the possibility to live here in Vercelli YYY: I've seen you looking for a while, I found my babysitter in a group of babysitters here on

46 In Italy, the label latino has not taken on the economic or political significance that it holds in the United States (Dávila 2008), and neither has it acquired a racial connotation (Garcés-Conejos Blitvich and Bou-Franch 2014). For Italians, this term is typically associated with the world of music and popular culture, and only takes on a negative aspect if used to refer to Latino Gangs, which are often associated with crime and violence.

47 ZZZ: Hola a todos, hace un año me vine a vivir a Italia, [ . . ] ] No se a ustedes, pero a mí en lo personal me cuesta aún entender a los Italianos en la relación amistad. El Argentino es único y extraño a mis amigos ... Si alguno anda por ésta zona y tiene ganas de hacer una charla o de compartir un rato, algún día se puede organizar algo. Besos a todos! XXX: Estaría bueno hacer un gran asado con una mesa súper larga y juntarnos todos!!!! YYY: Te invito cuando quieras trae el mate yo no tengo jaja

48 Tuve la suerte d conocer chicos muy buenos de Torino q me presentaron mas personas, pero nunca sera igual a la amistad argentina. 
Facebook $[\ldots]$

XXX: Yes, thank you, I was hoping to find someone from Colombia (COLenIT) ${ }^{49}$

Meanwhile, when events reported in these groups show LAs as protagonists of negative actions in Italy, the comments display a rejection of these compatriots, expressing their desire to distance themselves from "them" and highlighting the positive qualities of the group with the use of the first person plural ("we", in (44)) as opposed to "them" (42), those committing criminal acts:

42. They are criminals (PEenIT) $)^{50}$

43. A classic, he should be permanently expelled (PEenIT) ${ }^{51}$

44. The majority of Colombians in Italy are peaceful, honest, hardworking and we reject the brutality that took place in Milan and all the manifestations of violence [ ... ] let's protect our community and the community that hosts us [ ... ] let's denounce violent people (COLenIT) ${ }^{52}$

On the other hand, despite obtaining Italian citizenship, which, as we mentioned earlier, is a moment of pride and happiness, these migrants always emphasise their national identity, in line with the transnational condition in which they live:

\section{I have Italian citizenship, but I am Colombian (COLenIT $)^{53}$}

\subsection{Language}

Language operates, in its own right, as an identity marker in the tension between maintenance of the mother tongue and language change (De Fina et al. 2006). Code switching, understood as the alternation of more than one language, is a typical phenomenon of bilingual discourse and can be a resource for the negotiation and construction of identity (Dumitrescu 2014). The use of the language of the host country can be considered as an index of the level of integration achieved, of a greater level of attention to the new context and, sometimes, to the interlocutor who may be Italian, as found in semi-directed interviews (Calvi 2011). In the Facebook groups, however, there is greater control of the conversation, perhaps because this is an asynchronous medium and the dialogue is not in real time. In this social network, Spanish is considered to be a marker of identity; it has been suggested that its primacy might stem from the fact that many users post their messages and ask for advice from the country of origin before emigrating, something that is confirmed by a post which states: " $[\ldots]$ in the group there are people from all over" (ARGenIT). Moreover, when someone writes in Italian, she or he is immediately asked why she or he does so. In example (46), a university student writes a long post in which she gives information about the linguistic habits of the Spanish speakers living in Italy, she is asked why she does not write in Spanish, since the group is constituted mainly by LAs:

46. I see in your profile that you know Spanish, why are you writing in Italian here? (PEenIT) $)^{54}$

On other occasions the members of the group criticise and make fun of poor use of Italian, suggesting the use of Spanish:

47. Sometimes makes you laugh ... they want to write in Italian on a page in Spanish and what's worse, they write it badly (PEenIT) ${ }^{55}$

49 Hola sigo buscando ninera empleada, medio tiempo doy la disponibilidad de vivir aca en Vercelli. YYY: Hace rato que te veo buscando, yo encontré mi niñera en un grupo de babaysitters acá en Facebook [ ... ]. XXX: Sí, gracias, mi intención era buscar a alguien colombiano.

50 Son unos delincuentes.

51 Un clasico, deberían expulsarlo definitivamente.

52 La mayoría de colombianos en Italia somos pacíficos, honestos, trabajadores y rechazamos la brutalidad ocurrida en Milán y toda la manifestación de violencia [ ... ] portejamos nuestra comunidad y la comunidad que nos hospita [ ... ] denunciemos los violentos.

53 Tengo ciudadanía italiana, pero soy colombiano.

54 Veo en tu perfil que sabes castellano, por qué escribe en italiano aquí.

55 A veces es como para reirse. quieren escribir en italiano en una pagina en español y para colmo lo escriben mal. 
Nevertheless, it is possible to find some signs of the contact with the Italian language. These hybrid, innovative and creative discursive praxes, also favoured by the grammatical closeness of the two languages that make up the bilingual repertoire of the LAs in Italy, represent a strategy to which speakers resort in an active and conscious way in order to negotiate multiple identities and to create a new social space in which to position themselves. In SNS, we observe a "Spanish in motion" that represents the way in which "the Hispanic-American population relocate their linguistic practices and at the same time affirm their transnational identity and create a new social space" (Bonomi 2018).

We can trace then, some borrowed words that are used to introduce terms related to the areas of work, food, bureaucracy and other realities pertaining to Italy, such as "codice fiscale", "permesso di soggiorno", "badante", "comune", "nulla osta", "Prefettura", "Questura", and "affettati"; likewise, hybrid forms appear, such as "permiso de [Spanish] soggiorno [Italian]" or "salumes", which employs a Spanish plural form applied to the Italian term for "cold cut", a linguistic phenomenon that also takes place in the case of the neologism "badantes" ("old people's care worker"). We find the same practices of codeswitching and borrowed words in the ethnic media (Mapelli 2010, 2014) and in the semi-structured interviews (Calvi 2011; Bonomi 2018):

48. To marry in Italy you must reside in a comune, bring her birth certificate from Argentina (stamped), go to the consulate to place the nulla osta [authorisation], legalise it in the Prefettura and then make an appointment. These are presented to the questura along with the marriage certificate and they give you the form to request the permesso di soggiorno (COLenIT) $)^{56}$

49. I want to apply for the permiso de soggiorno, can someone tell me what to do? (ARGenIT) $)^{57}$

50. XXX: I'm going to travel to Colombia and I wanted to know if you can take affettati YYY: Salumes if they are vacuum packed (COLenIT) $)^{58}$

The corpus contains other examples of words and phrases in Italian with no particular cultural resonance, but which are very frequent in everyday life ("bellissima", "brutto", "ci sarò") or formulas for greetings, thanks or congratulations ("Buona domenica"; "Buongiorno Padova", "Tanti auguri!", "Bravissima!"), and typical expressions from the field of professions and employment ("pizzaiolo", "mestiere", "lavoro", "con esperienza", "capo", etc.). We also find traces of functional words, such as "mah", "boh", to express doubt, or "cioè" to reformulate. Italian thus serves to emphasise still further the user's level of integration and to reaffirm a plural identity:

51. I've been here for 12 years [ ... ] Venite a Italia! E' bellissima (ARGenIT) $)^{59}$

52. Italy is going through a brutto moment (COLenIT) $)^{60}$

53. Ask if your capo will give you a contract (PEenIT) ${ }^{61}$

54. In your case you would have a better chance in other countries [ . . ] boh I don't know (URenIT) ${ }^{62}$

Sometimes the Italianism is preceded by a translation:

55. You can get a job as an old people's carer (badante) $\left(\right.$ PEenIT) ${ }^{63}$

The penetration of Italian may also observed in some morphosyntactic structures, such as, for example, the use of the article in front of the possessive adjective ( ${ }^{*} \mathrm{El}$ mío consejo $=$ My advice), the use

\footnotetext{
56 Para casarse en Italia deben residir en un comune, traer de argentina el acta de nacimiento de ella (apostillada), ir al consulado a colocarle el nulla osta, legalizarlo en la Prefettura y luego sacar turno. Con el acta de matrimonio se presentan a la questura y te dan el formulario para solicitar el permesso di soggiorno.

57 Quiero solicitar el permiso de soggiorno, alguién me puede decir que hacer?

58 XXX: Voy a viajar a Colombia y queria saber si se pueden llevar 'affettati'. YYY: Salumes sì empaquetados al vacío.

9 Llevo aquí 12 años [ ... ] Venite a Italia! E' bellissima.

Italia está pasando por un brutto momento.

Pregunta si tu capo te hace un contrato.

2 En tu caso tendrías más oportunidad en otros país ... boh no sé.

63 Puedes conseguir trabajo como acompañante de ancianos (badante).
} 
of the verb "recomendar" with "de + the infinitive" rather than "recomendar que + subjunctive", or the use of the preposition "en" instead of "a" (“*Te recomiendo de no venir en Italia" - "I recommend you don't come to Italy").

Although Spanish is dominant, the importance of learning Italian to find work is underlined. Indeed, we often encounter advice such as: "you'll need to know some Italian"; "I would invest in the language":

56. You should know some Italian so that you can communicate [ ... ] and go to the police as soon as you arrive (PEenIT) ${ }^{64}$

57. If I were you, I'd invest in the language [Italian] from Argentina, and I'd work on perfecting it on a daily basis (ARGenIT) ${ }^{65}$

It should also be noted that in the group of Argentinians, Italian courses are announced, and the learning of Italian is encouraged through videos and tables explaining some L2 grammar rules, since LA migrants consider that knowing the language favours the integration process and the search for a job. The administrator of the group published, during a period, some videos explaining some grammatical rules of Italian. This is because Argentinians, in many cases, have Italian origins and already know Italian when they arrive in Italy.

\section{Conclusions}

Facebook groups respond to the human need to meet, dialogue, exchange information, and express one's concerns and experiences. Particularly, in the case of migrants, this need is accentuated by a feeling of loneliness and disorientation before and after the trip, when different problems of adaptation need to be addressed and a number of bureaucratic procedures have to be gone through. Such groups provide psychological benefits, offering moral support to many and a magnetic pole for people who wish to emigrate, since they praise the success achieved by the group in Italy or mitigate the narratives about the difficulties encountered; they also provide practical benefits in the form of concrete information about the migration process. In addition, as a discursive practice, Facebook is configured as a privileged space for the negotiation and construction of identity. These groups create a feeling of "community belonging" (Busso 2016) by the fact of being able to share content and personal experiences to create a connection with "friends" both here and over there and by generating trust. In these groups people seek a psychological refuge, an identity based on the sentimental ties that connect people to their country of origin and that are often translated into manifestations of nostalgia towards some cultural or characteristic aspect thereof, with a continuous oscillation between the country of origin and the host nation. The user's sense of identity tends to privilege references to the home country and the use of Spanish to communicate, although we also observe that there is a good level of integration into the new context and that their language is permeable to the influence of Italian.

In addition to this "affiliation" with members of the same group, a "disaffiliation" (Blas Arroyo 2009) is observed with respect to citizens who are stigmatised for having committed a criminal act.

To conclude, we can affirm that, despite the separation of members from their distant places of origin, in migrant Facebook groups, ties with their cultural, political, economic and linguistic roots are not merely unbroken, but are indeed strengthened (De Fina 2014). Thus, SNS become "transnational social spaces" (Faist 1998), that is, fluid environments, without geographical or territorial limits, in which a community reinforces the bonds of solidarity that derive from a shared conception of collective identity, and in which ideas, symbols and cultural materials circulate. The internet and social media forge a deterritorialised "community of feeling". Within SNS, the migrant experiences a

64 Deberías saber algo de italiano para poder comunicar ... e ir a la policía apenas llegas.

65 En tu lugar le metería al idioma [italiano] desde Argentina, e iría a perfeccionarlo en el día a día. 
double-belonging and (re)builds his/her identity, maintaining a strong attachment to his/her country of origin even though he/she makes adjustments, reinterpreting that identity to establish the foundations for a balanced integration, conscious of the fact that he/she will need to adapt to the new context, without forgetting his/her own roots. Migrants thus set themselves up as actors who operate in different political and economic environments that connect different places, intertwining relationships that encompass the country of origin and the host community (Ambrosini 2008).

We therefore share Diminescu's (2008) notion of the 21st century migrant as someone who cannot be defined through ideas of fractured spaces and borders, but rather by concepts of mobility and connectivity, characteristics that change the migratory experience and the management thereof. We will leave for future research the quantitative analysis of linguistic strategies employed in these contexts, as well as the study of multimodal aspects, with the aim of gaining a more complete picture of identity construction in SNS.

Funding: This research received no external funding.

Conflicts of Interest: The author declares no conflict of interest.

\section{References}

Ambrosini, Maurizio. 2008. Un'altra Globalizzazione. La Sfida Delle Migrazioni Transnazionali. Bologna: Il Mulino. Atkinson, Robert. 1998. The Life Story Interview. London: Sage.

Bauman, Zygmunt. 2011. Facebook, L'intimità e L'estimità. Bari: Laterza.

Benwell, Bethan, and Elizabeth Stokoe. 2006. Discourse and Identity. Edinburgh: Edinburgh University Press.

Blas Arroyo, José Luis. 2009. Manifestaciones de la identidad lingüística en el mundo hispánico. In Identidades Sociales e Identidades Lingüísticas. Coordinated by José Jesús Bustos Tovar and Silvia Iglesias Recuero. Madrid: UCM, pp. 119-57.

Boccaglia, Paolo. 2011. Transnazionalismo e percorsi familiari: Profili di genere e di generazione a confronto nell'immigrazione ecuadoriana. Studi di Sociologia 4: 385-404.

Boccagni, Paolo. 2009. Tracce Transnazionali. Vite in Italia e Proiezioni Verso Casa tra i Migranti Ecuadoriani. Milano: FrancoAngeli.

Bonomi, Milin. 2010. Hablamos mità y mità. Varietà linguistiche di immigrati ispanofoni in Italia. In Lingua, Identità e Immigrazione. Prospettive Interdisciplinari. Edited by Maria Vittoria Calvi, Giovanna Mapelli and Milin Bonomi. Milano: FrancoAngeli, pp. 53-69.

Bonomi, Milin. 2018. Mestizos Globales. Transnacionalismo y Prácticas Discursivas en la Población Hispana en Italia. Milano: FrancoAngeli.

Busso, Mariana. 2016. Grupos de migrantes en Facebook: Los reacomodamientos íntimos de la identidad nacional. Inmediaciones de la Comunicación 11: 229-49. [CrossRef]

Calvi, Maria Vittoria. 2011. Aspectos del español hablado por los inmigrados hispanoamericanos en Italia. In Sintaxis y Análisis del Discurso Hablado en Español: Homenaje a Antonio Narbona. Coordinated by José Jesús de Bustos Tovar, Rafael Cano-Aguilar, Elena Méndez García de Paredes and Araceli López Serena. Sevilla: Universidad de Sevilla, vol. 1, pp. 155-72.

Calvi, Maria Vittoria. 2015a. Etiquetas étnicas e identidad en entrevistas a hispanoamericanos en Italia. In Identità e Discorsi. Studi Offerti a Franca Orletti. Edited by Laura Mariottini. Rome: Roma TrePress, pp. 111-30.

Calvi, Maria Vittoria. 2015b. Spagnolo e italiano nelle seconde generazioni di migranti ispanofoni in Italia. Quaderns d'Italià 21: 45-62. [CrossRef]

Caselli, Marco. 2009. Vite Transnazionali? Peruviani e Peruviane a Milano. Milano: FrancoAngeli.

Chen, Wenli. 2010. Internet-usage patterns of immigrants in the process of intercultural adaptation. Cyberpsychology, Behaviour, and Social Networking 13: 387-99. [CrossRef] [PubMed]

Chiesi, Antonio M., and Eugenio Zucchetti, eds. 2003. Immigrati Imprenditori. Milano: Egea.

Damian, Elena, and Erik Van Ingen. 2014. Social Network site usage and personal relations of migrants. Societies 4: 640-53. [CrossRef]

Dávila, Arlene M. 2008. Latino Spin. Public Image and the Whitewashing of Race. New York: New York University Press.

De Fina, Anna. 2006. Group Identity, Narrative and Self Representations. Edited by Anna de Fina, Deborah Schiffrin and Michael Bamberg. Cambridge: Cambridge University Press, pp. 351-75. 
De Fina, Anna. 2007. Parlando di mangiare. La costruzione interazionale dell'identità. In La Costruzione Interazionale Dell'identià. Repertori Linguistici e Pratiche Discorsive Degli Italiani in Australia. Edited by Anna Ciliberti. Milano: FrancoAngeli, pp. 68-89.

De Fina, Anna. 2014. Spazi transnazionali di costruzione delle identità: I latinos negli Stati Uniti. In Lingue Migranti e Nuovi Paesaggi. Edited by Maria Vittoria Calvi, Irina Bajini and Milin Bonomi. Milano: LED, pp. 215-32.

De Fina, Anna, Deborh Schiffrin, and Michael Bamberg, eds. 2006. Discourse and Identity. Cambridge: Cambridge University Press.

Diminescu, Dana. 2008. The connected migrant: An epistemological manifesto. Social Science Information 47: 565-79. [CrossRef]

Dumitrescu, Domnita. 2014. La alternancia de lenguas como actividad de imagen en el discurso hispanounidense. Pragmática Sociocultural 2: 1-34.

Faist, Thomas. 1998. Transnational social spaces out of international migration: Evolution, significance and future prospects. Archives Européennes de Sociologie 39: 213-47. [CrossRef]

Ferrer, Raquel, Jorge Palacio, Olga Hoyos, and Camilo Madariaga. 2014. Proceso de aculturación del inmigrante: Características individuales y redes sociales. Psicología desde el Caribe 31: 557-76. [CrossRef]

Garcés-Conejos Blitvich, Pilar, and Patricia Bou-Franch. 2014. ¿iHispano y blanco?!: Racialización de la identidad latina en YouTube. DiscursoESociedad 8: 427-61.

Garreta Bochaca, Jordi. 2016. Asociacionismo e inmigración. El papel de las asociaciones de inmigrantes en España. Intercambio/Échange 1: 164-80.

Hymes, Dell. 1996. Ethnography, Linguistics, Narrative Inequality: Toward an Understanding of Voice. London: Taylor and Francis.

Jankowski, Noam. 2006. Fare comunità con i media: Prospettive storiche, teoriche e di ricerca. In Capire I New Media. Culture, Comunicazione, Innovazione Tecnologica e Istituzioni Sociali. Edited by Leah A. Lievrow and Sonia Livingstone. Milano: Hoepli, pp. 37-66.

Kluge, Bettina. 2015. The Joint Construction of a Supranational Identity in the Latin American Blogging Community in Quebec. In A Sociolinguistics of Diaspora. Latino Practices, Identities, and Ideologies. Edited by Rosina Márquez Reiter and Luisa Martín Rojo. New York and London: Routledge, pp. 181-95.

Knauer, Gabriele. 2005. Lengua y medios de comunicación étnicos: El caso del español en EE. UU. In El Español en América. Aspectos Teóricos, Particularidades, Contactos. Edited by Volker Noll, Klaus Zimmermann and Ingrid Neumann-Holzschuh. Madrid and Frankfurt: Iberoamericana/Vervuert, pp. 133-50.

Komito, Lee. 2011. Social Media and Migration: Virtual Community 2.0. Journal of the American Society for Information Science and Technology 62: 1075-86. [CrossRef]

Leurs, Koen, and Sandra Ponzanesi. 2018. Connected migrants: Encapsulation and cosmopolitanization. Popular Communication 16: 4-20. [CrossRef]

Licoppe, Christian. 2004. 'Connected' presence: The emergence of a new repertoire for managing social relationships in a changing communication technoscape. Environment and Planning D: Society and Space 22: 135-56. [CrossRef]

Mapelli, Giovanna. 2010. Informazione e multiculturalità: Il caso di Expreso Latino. In Lingua, Identità e Immigrazione. Prospettive Interdisciplinari. Edited by Maria Vittoria Calvi, Giovanna Mapelli and Milin Bonomi. Milano: FrancoAngeli, pp. 173-89.

Mapelli, Giovanna. 2014. Il caso Hola mi gente-Ciao amici. Rivista Trimestrale di Scienza dell'Amministrazione 4: 105-18.

Mariottini, Laura. 2014. Spazio latino nei discorsi pubblici mediati: Radio Mambo. RTSA 4: 117-29. [CrossRef]

McGregor, Elaine, and Melissa Siegel. 2013. Social Media and Migration Research. MERIT Working Papers 068, United Nations University-Maastricht Economic and Social Research Institute. Available online: https: //migration.unu.edu/publications/working-papers/social-media-and-migration-research.html (accessed on 10 October 2017).

Melella, Cecilia. 2013. Del Inmigrante Desarraigado al Migrante Conectado. La Construcción de Identidades de los Colectivos Andinos en la Argentina a Través de la Web. Buenos Aires: Instituto de Investigaciones Gino Germani.

Mera, Carolina. 2010. El concepto de diáspora en los estudios migratorios: Reflexiones sobre el caso de las comunidades y movilidades coreanas en el mundo actual. Revista de Historia 12: 1-18. 
Portes, Alejandro, Luis Guarnizo, and Patricia Landolt. 1999. The Study of Transnationalism Pitfalls and Promise of an Emergent Research Field. Ethnic and Racial Studies 22: 217-37. [CrossRef]

Vela Delfa, Cristina. 2014. Estrategias de construcción y mantenimiento de la imagen pública en canales de chat. Aposta. Revista de Ciencias Sociales 63. Available online: http://apostadigital.com/revistav3/hemeroteca/cvela1. pdf (accessed on 20 July 2018).

Vertovec, Steven. 1999. Conceiving and researching transnationalism. Ethnic and Racial Studies 22: 447-62. [CrossRef]

Vincent, Jane. 2015. Stayig in Touch with My mobile Phone in My Pocket and Internet in the Cafés. In $A$ sociolinguistics of Diaspora. Latino Practices, Identities, and Ideologies. Edited by Rosina Márquez Reiter and Luisa Martín Rojo. New York and London: Routledge, pp. 169-80.

Yus Ramos, Francisco. 2011. Ciberpragmática 2.0. Nuevos usos del lenguaje en Internet. Barcelona: Ariel.

Yus Ramos, Francisco. 2014. El discurso de las identidades en línea: El caso de Facebook. Discurso E Sociedad 8: 398-426.

Zijlstra, Judith, and Ilse Van Liempt. 2017. Smart (phone) travelling: Understanding the use of impact of mobile technology on irregular migration journeys. International Journal of Migration and Border Studies 3: 174-91. [CrossRef]

(C) 2019 by the author. Licensee MDPI, Basel, Switzerland. This article is an open access article distributed under the terms and conditions of the Creative Commons Attribution (CC BY) license (http://creativecommons.org/licenses/by/4.0/). 